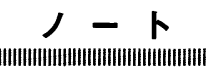

\title{
バッチ式オゾン処理による非密封 RI 施設排水の殺菌脱臭システム
}

\author{
川村熙子，田口研二*，平田恭記 \\ 九州大学アイソトープ総合センター \\ 812-8582 福岡市東区馬出 3-1-1 \\ *(株) 理研
}

807-0813 福岡県北九州市八幡西区夕原 8-2

2001年12月18日＼cjkstart受理

Key Words : automatic deodorizing system, ozone generator, waste water, radioisotope facility

\section{1.はじめに}

生物系試料を実験材料に用いることが多い医 歯薬系の非密封 RI 施設の管理において, 苦慮 することのひとつが希釈槽から排水を放流する 際の悪臭である。一般排水のように常時放流す ることはできない。施設の規模にもよるが，ス テンレス製タンクの中に数トン以上貯めて, 場 合によっては RI の物理的減衰を待って放流す る, というのが一般的であろう。その間に有機 物の腐敗が進み, 放流の際に, 流し, トイレ排 水口から悪臭が逆流し, 当センター建物内のみ ならず周辺の大気中に拡散していく。昨今の環 境への意識の高まりからか，空を開放する季節 になると近隣の建物から苦情の電話が入るよう になった。

排水放流時の臭気対策として, 簡便で, 既設 の排水設備に損傷を与えることなく，使用後に 環境負荷物質を残さず，安価である，等の条件 の下に，オゾン酸化によるバッチ式処理を試み た。㥶用的で十分な殺菌脱臭効果があることを 確認できたので報告する。

\section{2. 装置選定・システム構成の条件}

排水の殺菌脱臭方法および装置を，以下の条 件で選択し構成した。

（1）使用後に残留物を生じる化学薬品を使
用しない。

オゾンは有機物との酸化反応後, 瞬時に分解 し酸素となるため環境への負荷を考慮する必要 がない。

（2） 既設の排水貯留槽，槽内の機器および その周辺設備等に故障となる原因を与えない。 オゾンは極めて酸化力が強く, 排水モニ夕 . 水中ポンプ・電磁弁等を損傷させる可能性があ る。これらを回避するため, オゾン発生器を既 設排水設備のコンクリート壁の外側に設置し, バッチ式で排水オゾン処理を行う。

（3）管理室内に既設の排水処理遠方操作盤 と連動する。

管理室で遠方操作盤の排水開始ボタンを押す だけで，排水完了までの工程が自動的に行える 構成とする。

（4）昼夜自動連続運転ができる。

オゾン酸化反応は短時間であるため, 少量ず つの排水処理が効率よく殺菌脱臭できる。当施 設では 1 回の排出量 $30 \mathrm{~m}^{3}$ に約 10 時間を要して いる。オゾン処理の工程が加わると 1 回の排出 に $2-3$ 昼夜を要するため, その間無人運転で きなければならない。

（5）周辺域への環境や装置コストを考慮し, オゾンガス溶解効率がきわめて高い溶解装置で あること。

従来の散気管による注入方式では，注入オゾ 
ンガスの $90 \%$ 程度の排オゾンガスがでる。

（6）装置および設置費用が安価であり，特 別の予算措置を必要としない。

\section{3. システムの概要}

本システムは，既設の RI 施設排水設備希橎 槽と下水道との間に処理タンクを設置し，希釈 槽からの排水をタンク内において少量のオゾン ガスで殺菌脱臭処理を施した後, 下水道へ排水 する一連の工程を既設設備と連動させる，自動 連続運転仕様の排水殺菌脱臭装置である。シス テムの構成を Fig.1に示す。図中の装置仕様は 下記のとおりである。

(1)排水処理タンク：処理能力 $1 \mathrm{~m}^{3}$ 回

(2)PSA（酸素発生器）：4L $\mathrm{Lin}$

(3)オゾナイザー（オゾン発生器）：1 g/h

(4)高効率ガス溶解装置 (GENKI02)

(5)装置運転制御装置

(2)～(5)は本体庫内収納機器)
運転工程を以下に示す。排水オゾン処理時間 は $0.5 ， 1.0 ， 1.5 ， 2.0 ， 2.5 ， 3.0$ 時間に設定可 能である。

（1） 希釈槽より (1)排水処理タンクへ $1 \mathrm{~m}^{3}$ 給 水

（2）(2PSA が運転開始

（3） 2 分後に(3)オゾナイザーが運転開始

（4）さらに 2 分後に(4)GENKI02が始動

（5）排水オゾン処理

（6）タイムアップ，(4)GENKI02停止

（7）処理排水を下水道へ排出開始

（8）２分後に(3)オゾナイザー, (2)PSA 停止

（9）各機器が次の給水まで待機状態

（10）（1）～（9）までの工程を繰り返し行う

本システムに故障, トラブルが発生すると, 管理室内の排水処理遠方操作盤，屋外に既設の 水処理動力現場盤内に増設した異常灯が点灯し， 各機器は運転を停止する。

本システムが使用できない事態が発生した場

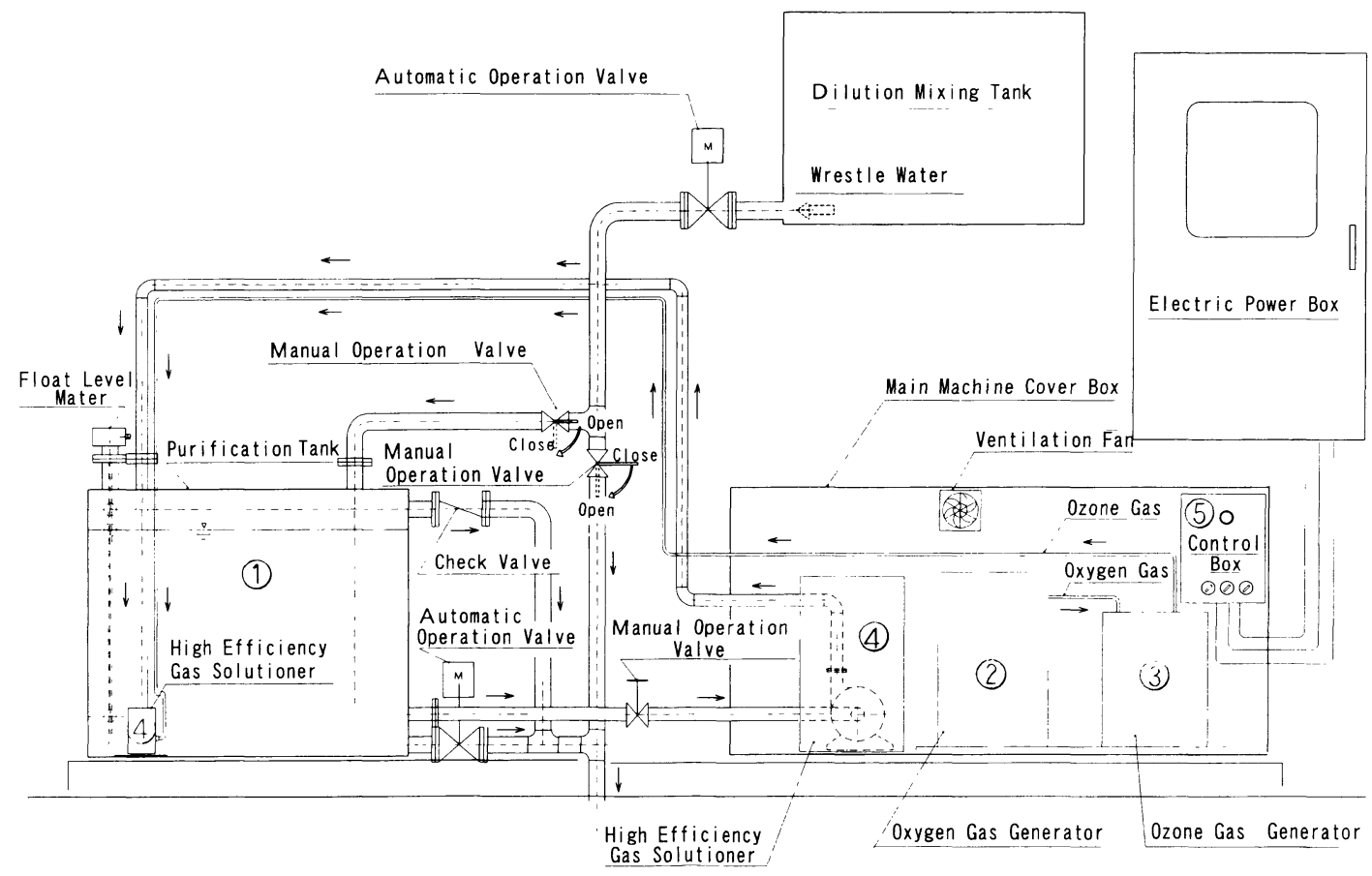

Fig. 1 Flow chart. 
合は，下記の手順で従来の排水運転ができるよ うに設計されている。

（1） 既設の水処理動力現場盤内に増設して いる[殺菌脱臭装置］セレクトスイッチを「通 常」から「バイパス」に切り替える。これによ り従来の電気信号回路に復帰する。

（2）(1)排水処理タンク横の丁字管部分の「手

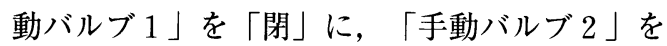
「開」にする。これにより従来の下水道への排 水経路になる。

\section{4. 性 能試験}

\section{$4 \cdot 1$ 水質試験項目}

当センターは, 医・歯学部および附属病院, 薬学部, 医療技術短期大学部を含む病院地区キ ヤンパスに位置する，唯一の非密封 RI 実験施 設である。700名を超す利用者の大多数が生物 試料を実験材料としている。排水中には培養液, 動物細胞・血液・尿, 遺伝子実験に使用された 大腸菌等が混在することを考慮して以下の測定 項目を選択した。

臭気については，あらかじめ検知管により硫 化水素が主因であることを確認しておいた。

一般項目 : 水素イオン濃度 $(\mathrm{pH})$, 測定時水 温, 生物化学的酸素消費量 (BOD), 浮遊懸濁 物質量 (SS), $n$-ヘキサン抽出物質（油脂類） 含有量, 大腸菌群数

追加項目 : 硫化水素濃度, アンモニア濃度,
硫化物濃度，酸化還元電位（ORP）

\section{$4 \cdot 2$ 測定方法}

本システムの稼動開始は 2001 年 3 月 27 日であ るが, 性能試験は有機物の分解, 嫌気性細菌類 が最も繁殖増加する夏期に, 3 回測定を行った。 測定は (財) 九州環境管理協会, (株) 新日本環境 計測に依頼した。測定・計量はいずれも JIS ま たは環境庁告示に基づき行った。

当センターの排水設備は貯留槽 $\left(40 \mathrm{~m}^{3}\right) \quad 3$ 基, 希釈槽 $\left(40 \mathrm{~m}^{3}\right) \quad 1$ 基から成るが, 実効貯 水量はそれぞれ約 $30 \mathrm{~m}^{3}$ である。2週間 - 1 か月 で満水するが，希釈水を使用せず，RIの物理 的隇衰を待って排水している。貯水・排水日程 および測定日との関係を Table 1 に示す。

第 1 回：6 月21日測定。貯留槽への流入開始 から45日目の排水を,オゾン未処理(原水), 0.5 時間オゾン処理 (0.5 時間処理水), 1 時間オゾ ン処理（1 時間処理水）した後に測定。硫化水 素・アンモニア測定は検知管による。

第 2 回：8月 2 日測定。流入開始から 22 日目 の排水。原水, $1 \cdot 1.5 \cdot 2$ 時間処理水を測定。 硫化水素・アンモニア測定は検知管による。

第 3 回：9 月21日測定。流入開始から55日目 の排水。原水, $1 \cdot 1.5 \cdot 2$ 時間処理水の硫化水 素, アンモニア, 大腸菌群数のみ測定。硫化水 素はガスクロマトグラフ分析, アンモニアは吸 光光度分析による。

$\begin{array}{lllll}\text { May. } 7 & \text { Jun. } 5 & \text { Jun. } 26 & 0.49 & \text { Jun. } 21 \\ \text { Jul. } 11 & \text { Jul. } 28 & \text { Aug. } 8 & 0.47 & \text { Aug. } 2 \\ \text { Jul. } 28 & \text { Aug. } 22 & \text { Oct. } 1 & 0.42 & \text { Sep. } 21\end{array}$




\section{5. 結果および考察}

測定結果を Table 2 に示す。

$n$-ヘキサン抽出物質には, 鉱物油類, 動植 物油脂類，界面活性剂などが含まれる。排水基 準は動植物油脂類の場合 $30 \mathrm{mg} / 1$ 以下である1)。 第 1 回測定の結果，原水，オゾン処理水ともに $10 \mathrm{mg} / 1$ 前後であり，またオゾン処理による変 化も認められなかったので，第 2 回の測定項目 から除外し，硫化物，酸化還元電位を加えた。

硫化水素濃度は，第 1 回測定時の検知管では 原水, 0.5 時間処理水では，測定域 $(\leqq 60 \mathrm{ppm})$ を超え測定不能であった。

第 1 回測定における0.5時間処理水では，大 腸菌群数のみ原水の約 $1 / 2$ に減少したが，その 他の值は著変しなかったので，第 2 回以後オゾ ン処理時間を延長した。

3 回の測定により得られた特異な結果は次の
とおりである。

（1）原水中の大腸菌群数が著しく異なる。 排水の貯留日数 45 日で大腸菌 17000 個 $/ \mathrm{cm}^{3}, 55$ 日で230個 $/ \mathrm{cm}^{3}$ であるから，貯留期間中に大腸 菌が増殖したためとは考えられない。RIの使 用記録，利用者に対する聞き取り調查から，原 水中の大腸菌群数の多少は実験に使用された大 腸菌の多少に因ることが判明した。

オゾンによる殺菌効果は，大腸菌が多い場合 に著効するが，200個 $/ \mathrm{cm}^{3}$ 程度までは効果が認 められない。下水道への排出規制值には大腸菌 群数の項目は定められていない。しかし，下水 道からの放流水の基準值が 3000 個 $/ \mathrm{cm}^{3}$ 以下で あるので2)，17000個 $/ \mathrm{cm}^{3}$ の原水でも 1 時間才 ゾン処理を行えば環境への放流が可能となる。

（2）原水中の硫化水素濃度は，第 1 回測定 では携帯した検知管の測定域（ $\leqq 60 \mathrm{ppm）を}$ 超えたが，臭覚的にも第 2 回，第 3 回測定時に 比し，悪臭がきわめて激しく，大腸菌群数も第

Table 2 Results of water examination

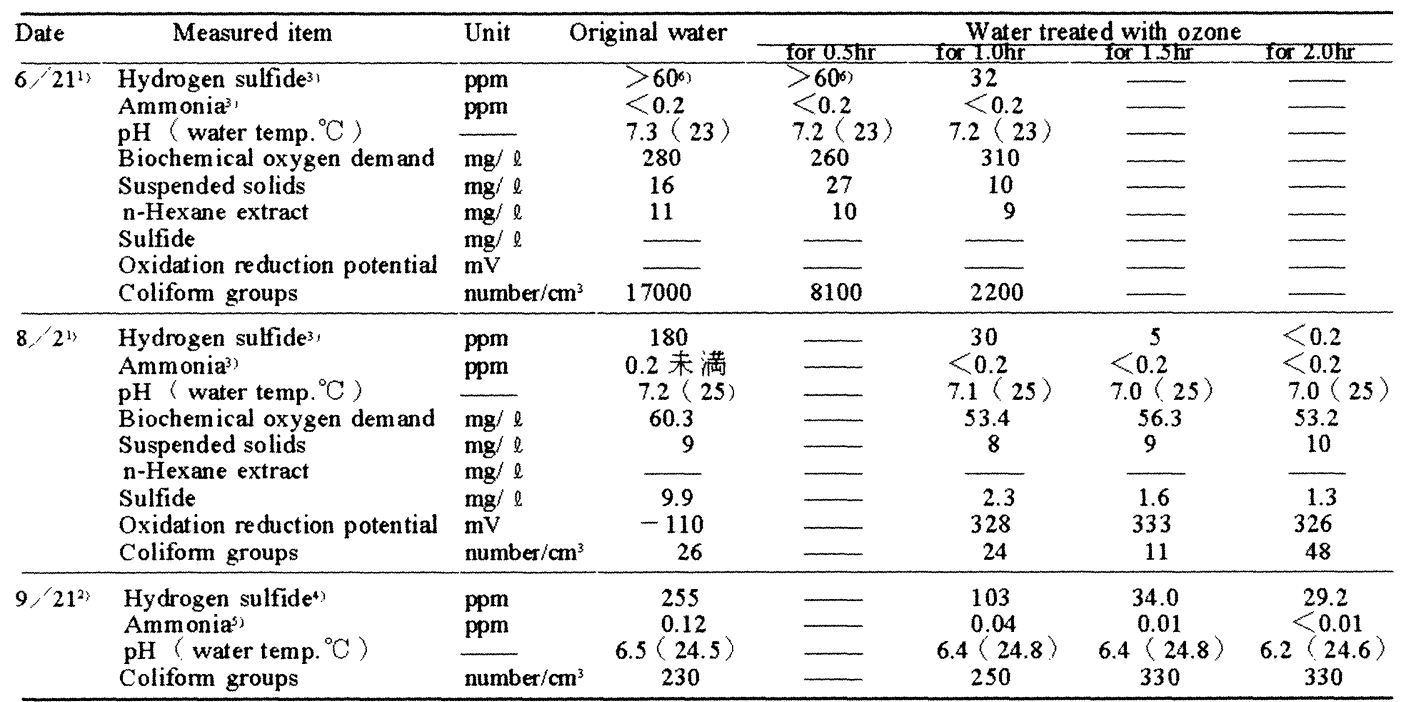

1) Analyst : Kyushu Environmental Evaluation Association.

2) Analyst : New Japan Environmental Measurement, Co. Ltd.

3 measured with gas detector tubes ; 4) measured by gas chromatography ; 5) measured by absorptimetry

6) exceed the limit of measurement by the detector tube carried on the day of examination 
2 回測定の650倍，第 3 回測定の75倍であった。 オゾン処理時間の延長に伴って，硫化水素濃度 および臭気は著明に減少し， $30 \mathrm{ppm}$ 程度以下 で悪臭はほとんど感じられなくなった。

アンモニア濃度は原水中 $0.12 \mathrm{ppm}$ であり， オゾン処理時間の延長に伴い減少している。

原水中の硫化水素とアンモニアの濃度比から， 臭気成分は主として硫化水素であると推定され る。

（3）生物化学的酸素消費量（BOD）は，水 中の好気性微生物の増殖時にエネルギー源とし て摂取される有機物分解に必要な消費酸素量を 意味するもので，有機污濁の指標とされている。 公共用水域へ排出する場合の排水基準は160 $\mathrm{mg} / \mathrm{l}$ とされているが2)，下水道に排出する場 合，小規模事業場では規制はない。

原水中の大腸菌群が多い第 1 回測定では, BOD が第 2 回測定に比し約 5 倍の值を示した。 オゾン処理は原水中の BOD が低い場合に減少 効果を発現できたが，処理時間延長による変化 は認められなかった。このことは，低濃度オゾ ン酸化処理に伴う現象のひとつである。排水中 の硫化水素は，嫌気性細菌の作用によって硫酸 塩が還元されて生成される。従って，排水中の 溶存酸素が $1 \mathrm{mg} / 1$ 以下でBOD 值が低い場合 は，排水中には嫌気性細菌（硫酸塩還元菌）が 主流であるため，オゾン酸化処理が有効である。 しかしオゾン酸化処理によって高濃度の酸素が 排水中に含まれることにより，嫌気性細菌を食 する原生動物（微生物），さらに原生動物を食 する後生動物（微生物）,さらには後生動物を 食する小動物（ミジンコ・イトミミズ）等の食 物連鎖（浄化作用）が促進される。すなわちオ ゾン酸化によって生じる酸素溶解によって嫌気 性細菌を食する好気性バクテリアの急激な増殖 により酸素消費量が増大されることである。昭 和 47 年に制定された現在の排水基準が，これか ら飛躍的に開発される高度処理に対し，適合性 が問われることとなろう。本オゾン酸化処理に よって生じる BOD の上昇は急激な浄化促進が
なされていることを意味するものである。

（4）酸化還元電位（ORP）, 硫化物濃度を オゾンガス発生器の能力およびオゾンの酸化力 の指標として測定した。オゾンは ORPが過酸 化水素, 塩素よりも高く, 硫化物は系により酸 化剂とも還元剂ともなりうる。排水は複雑な組 成をもっているので，これらの計量值の正確な 意味付けは難しいが, 実用上酸化還元処理工程 の管理に広く用いられている。

ORP はオゾン発生開始後 1 時間で急激に上 昇し, 以後プラトーに達した。硫化物濃度は逆 にオゾン発生後急激に減少し，以後漸減した。

（5）水素イオン濃度 $(\mathrm{pH})$ は6.2-7.3で中 性，オゾンによる変化はない。浮遊懸濁物質量 （SS）は大腸菌群数の多い原水で増加している が，オゾンによる一定の変化は認められなかっ た。

原水中の大腸菌群数が多い第 1 回測定におい て, 1.5 ・ 2 時間処理水のデー夕を欠いたこと, 第 $2 \cdot 3$ 回測定において 0.5 時間処理水のデー 夕もあれば，等々の反省点は残るが，以上の硫 化水素, 大腸菌群数, ORP, 硫化物のデー夕 から，最低 1 時間オゾン処理すれば十分な殺菌 効果を期待でき，人に悪臭を感じさせない程度 にまで脱臭できると推測された。

以来，オゾン発生時間を 1 時間に設定して排 水している。水中ポンプを使用しない自然落下 を利用するため, $30 \mathrm{~m}^{3}$ 排水するために 2 昼夜 半の時間を要するが，管理室で遠方操作盤の排 水開始ボタンを押すだけで，後は放置すればよ い。自らも悪臭に苛まされながら，周囲を気遣 う必要もなくなった。快適な排水環境となった。

\section{文献}

1）通商産業省環境立地局：“公害防止の技術 と法規〔水質編〕”， 5 訂，p. 339（2001）

2）日本環境測定分析協会：“環境計量必携”，p. 303 (2000) 


\section{Abstract}

Automatic Deodorizing System for Waste Water from Radioisotope Facilities Using an Ozone Generator.

Hiroko Kawamura, Kenji Taguchr ${ }^{*}$ and Yasuki HiRATA: Radioisotope Center, Kyushu University, 3-1-1, Maidasi, Higashi-ku, Fukuoka-shi 812-8582, Japan.

*Riken Co. Ltd., 8-2, Yuubaru, Yahatanishi-ku, Kitakyushu-shi 807-0813, Japan.

We applied an ozone generator to sterilize and to deodorize the waste water from radioisotope facilities. A small tank connected to the generator is placed outside of the drainage facility founded previously, not to oxidize the other apparatus, The waste water is drained $1 \mathrm{~m}^{3}$ at a time from the tank of drainage facility, treated with ozone and discharged to sewer. All steps proceed automatically once the draining work is started remotely in the office.

The waste water was examined after the ozone treatment for 0 (original), 0.5, 1.0, 1.5 and $2.0 \mathrm{~h}$. Regarding original waste water, the sum of coliform groups varied with every examination repeated probably depend on the colibacilli used in experiments; hydrogen sulfide, biochemical oxygen demand and the offensive odor increased with increasing coliform groups. The ozone treatment remarkably decreased hydrogen sulfide and the offensive odor, decreased coliform groups when the original water had rich coliforms.

(Received December 18, 2001) 